\title{
COOPERATIVE INTEGRATED READING AND COMPOSITION (CIRC) MODEL LEARNING PLAN IN IMPROVING ENGLISH READING SKILL
}

\author{
Rifqi Zaeni Achmad Syam¹, Rosiana Nurwa Indah², R. Supyan Sauri ${ }^{3}$, Farah Ruqayah4 \\ 1,2,3,4Universitas Islam Nusantara \\ 1,2,3,4Jalan Soekarno-Hatta No. 530 Bandung, Jawa Barat \\ Email: rifqisyam@uninus.ac.id ${ }^{1}$, rosiananurwaindah@uninus.ac.id ${ }^{2}$, uyunsupyan@uninus.ac.id ${ }^{3}$, \\ farah.ruqayah@uninus.ac.id ${ }^{4}$
}

\begin{abstract}
:
This study aimed to obtain an overview of the Cooperative Integrated Reading and Composition learning planning model to improve grade IX students' English reading skills at SMP Negeri 1 Jampang Tengah. The method used in this study was a descriptive method with a qualitative approach, and the research subjects were English teachers at SMP Negeri 1 Jampang Tengah. The data collection was done through document review, observation, and interviews. From the study results, it could be concluded that the Cooperative Integrated Reading and Composition Model's learning planning activities consisted of making annual programs, semester programs, syllabus, and lesson plans. In principle, it was good and appropriate to make lesson plans with the school's provisions and guidelines. Therefore, it was believed to achieve the specified competency standards and improve reading skills in English.
\end{abstract}

\begin{abstract}
Abstrak:
Penelitian ini bertujuan untuk memperoleh gambaran tentang perencanaan pembelajaran model Cooperative Integrated Reading and Composition dalam meningkatkan keterampilan membaca bahasa Inggris siswa kelas IX di SMP Negeri 1 Jampang Tengah. Metode dalam penelitian ini menggunakan metode deskriptif dengan pendekatan kualitatif. Subjek penelitian ini adalah guru bahasa Inggris di SMP Negeri 1 Jampang Tengah. Adapun Pengumpulan data dilakukankan melalui pengkajian dokumen, observasi dan wawancara. Dari hasil penelitian, dapat disimpulkan bahwa kegiatan perencanaan pembelajaran model Cooperative Integrated Reading and Composition terdiri dari pembuatan program tahunan, program semester, silabus dan RPP. Pada prinsipnya sudah baik dan sesuai dalam pembuatan perencanaan pembelajaran dengan ketentuan dan pedoman yang di tetapkan oleh pihak sekolah. Oleh karenanya, diyakini dapat mencapai standar kompetensi yang ditentukan dan dapat meningkatkan keterampilan membaca bahasa Inggris.
\end{abstract}

Keywords:

CIRC Model, Learning Plan, English Reading Skill.

How to Cite: Syam, R. Z. A., Indah, R. N., Sauri, R. S., \& Ruqayah, F. (2020). Cooperative Integrated Reading and Composition (CIRC) Model Learning Plan in Improving English Reading Skill. Lentera Pendidikan : Jurnal Ilmu Tarbiyah dan Keguruan, 23(2), 222-232. https://doi.org/10.24252/lp.2020v23n2i3. 


\section{INTRODUCTION}

In learning English, many teachers complain about the low ability of students to apply English concepts. It can be seen from the mistakes that the students made in answering questions in English. Given the students' oral and written exercises regularly, it could not improve students' ability to apply English concepts. On the other hand, students felt bored and did not want to study the teacher's learning material. Therefore, the teacher must create an interesting and fun exercise or assignment to make the students motivated and enthusiastic in learning English.

In the lesson plan, teachers as managers are required to carry out management strategies by implementing learning models to assess the achievements that students can achieve. It means that the teachers must be able to carry out tasks in planning and adequate knowledge and understanding of learning management disciplines. Learning activities are vital activities in the educational process. Teachers are educational implementers who have an essential role in achieving educational success. Likewise, teachers have a very important effect on the effort of increasing students' motivation (Yunus, 2016).

The success of educational programs through the teaching and learning process in schools as formal educational institutions is very helpful for several factors, namely: students, curriculum, educational staff, costs, facilities, and infrastructure, as well as environmental factors. If these factors can be fulfilled, it will certainly facilitate the teaching-learning process, which will support maximum learning outcomes and ultimately improve education quality (Anita, 2016).

A lesson plan is essential in the learning process at schools. Learning activities' success is primarily determined by teachers' and students' readiness to plan, organize, implement, and evaluate or monitor the learning process. According to Sagala (2010: 142-143), the implementation of the plan in learning management, in principle, includes: a) determining what the teacher will do, when, and how to do it in implementing learning; b) limiting targets based on of specific instructional objectives and establishing action to achieve maximum results through the process of determining learning objectives; c) developing alternatives by the learning strategy; d) collecting and analyzing vital information to support learning activities, and e) preparing and communicating plans and decisions related to learning to interested parties.

The teacher acts as an educator and facilitator in the lesson plan process. Through the learning process, the activity must provide motivations and perceptions regarding the material learned. Also, delivering the material must be clear, systematic, and potential to create a conducive classroom by developing good interpersonal relationships between teachers and students. It is done to realize an effective learning process. According to Mulyasa (2015: 36), the teacher must provide a reference in learning and make it easier for students to learn so that students can grow their potential.

English lesson plan is implemented at the junior high school level. The students who have successfully graduated from the junior high school level will have the ability and skills to speak English, both spoken and written. It is directed to the point that the 
students can understand and express information, thoughts, feelings and develop knowledge, technology, and culture by utilizing English. Besides, The English Lesson plan is expected to improve students' learning outcomes optimally. Moreover, English is one of the compulsory subjects in the National Examination. English as an international language plays a vital role as a means of communication in life. Especially in reading skills. Reading is one of the four English language skills that have a profound impact on society. By reading, a person can express thoughts and ideas to achieve specific goals and objectives. However, many people are still reluctant to learn English, from professionals, students, children, to adults and parents.

Learning English, especially for reading skills, is not as tricky as if you are serious about learning it by reading and writing. Furthermore, the application of the learning model can also be used to learn English. Reading is an essential part of the educational process (Harjono, 2011: 6). It is undeniable that we can effectively obtain most of our knowledge from reading books. We can also get whatever information we want through reading books. Without reading, it is not easy to imagine how the learning and education process can achieve.

Reading is an activity to obtain information from a text. Through reading, people can understand what the author is telling in his work. The understanding will be used in communication with other people. People who read a lot will get more knowledge than people who rarely or never read. With this knowledge, people can communicate in spoken or written form. In other words, reading can help one improve another's communication skills. However, the conditions for learning to read in schools are generally flawed by severe obstacles. Students' low reading interest evidences this obstacle because students cannot understand discourse in English.

According to Sari, Rostini, Fajarianto, \& Safitri (2020), reading is capturing and understanding ideas. An outpouring of their soul reflects the reader's activity in appreciating the script. That is why people said reading is the window of the world. By reading, we can see whatever happens in this world. Besides, we could also increase our knowledge, reading rate and also enrich our vocabularies. So, if people do not like to read, it means that they lack information (Sirait, Hutauruk, \& Herman, 2020). Reading is one aspect of the language skills that is a very useful activity for everyone, especially for students. Reading can extend the concept of knowledge, improve students' language skills, and enlarge their insight from the information they get from reading materials. In this way, the students read and comprehend the written text or reading material they read, that is, reading comprehension (Nurwanti, 2019). Thus, reading is an activity that is very important and beneficial for one's life because it makes a person have broad insight and knowledge. Reading is also a process carried out and used by readers to get messages, which the author conveys through written words/languages.

According to Saddhono \& Slamet (2014: 99-100), reading is not just calling out written symbols without questioning whether the series of words or sentences pronounced is understood or not, but more than that. However, such activity can still be called reading. Just keep in mind that reading instruction is classified as a type of 
introductory reading as is done by students in schools in the beginning grades. To overcome this, teachers must try to find appropriate strategies to help students improve their reading skills and motivate them to participate in English lessons, especially in reading instruction actively. Brown (2001: 320) suggests that the teacher acts as a facilitator who guides and directs students to create an exciting learning experience and motivate students. Therefore, teachers must be creative and selective in choosing models and compiling media. Because the model and media can improve and support teachers in learning activities in the classroom. As teachers, we must be able to decide the most relevant media and model and meet these requirements.

One of the popular models in English Learning is the Cooperative Learning Model. According to Sugiyanto (2010: 37), cooperative learning focuses on using small groups of students to maximize the learning environment to achieve learning objectives. This learning model is a model that prioritizes the existence of groups. In the cooperative learning model, students are allowed to collaborate with other friends through group discussions. Slavin in Isjoni (2010: 12) argues that cooperative learning is a model in which students learn and work collaboratively in small groups consisting of 4-5 members with a heterogeneous group structure. Meanwhile, Sunal and Hans in Isjoni (2010: 12) stated that cooperative learning is an approach or a series of strategies explicitly designed to encourage students to work together during the learning process.

Meanwhile, Cooperative Integrated Reading and Composition cooperative learning model is a cooperative learning technique used in language learning, namely in the instruction for high-level writing and reading skills. Students are placed in small heterogeneous groups; gender, ethnicity, and intelligence level are mixed. The steps in the CIRC model, according to Stevens in Huda (2014: 222), are as follows: a) The teacher forms groups of 4 heterogeneous members, b) The teacher provides discourses or clippings according to the topic, c) Students work together to read each other and find the main ideas and are expected to respond to discourse or clippings and write them on sheets of paper, d) Students present/read the results of group work, e) The teacher provides reinforcement and f) Closing.

According to Halimah (2014), to improve student learning outcomes is to apply learning methods that emphasize student activity in the learning process. By working and learning together, students are expected to develop their activeness without fear or embarrassment towards the teacher during the learning process. For that, it is necessary to develop learning methods that can involve students in the learning process so that few students dominate learning activities. One learning model involves all student participation in the cooperative learning model. In this case, the CIRC (Cooperative Integrated Reading and Composition) learning method is a method that uses group learning principles and emphasizes reading and writing integration.

Based on a preliminary study conducted by researchers at SMP Negeri 1 Jampang Tengah, Sukabumi Regency, English learning activities using the Cooperative model are always carried out when English occurs during the subject hours. Using cooperative learning will be more useful for the learning process. Because English learning contains 
four language skills; speaking, listening, reading, and writing, it is always taught to students using the Cooperative model with different techniques including Jigsaw Cooperative, Role Play, Snowball, Picture and Picture, NHT, CIRC, etc. However, the learning management process has not been optimal. It seems that it is not managed appropriately and systematically and carried out carelessly. In the learning process at SMP Negeri 1 Jampang Tengah, researchers also witnessed many student difficulties in facing English lessons. Many students do not like it and think English is a difficult subject.

Students' success in learning English will depend on themselves and the students' seriousness in learning English. Because many students fail to learn English, it could be due to the short time allocated for learning English in class, learning resources that are difficult to understand, inadequate infrastructure, wrong milieu, lack of support from family, etc. For this reason, the author will try to examine the problems described above in the title 'Lesson Plan with the Cooperative Integrated Reading and Composition model in improving English Reading Skills,' especially in class IX at SMP Negeri 1 Jampang Tengah, Sukabumi Regency. This research aims to know an overview of the English lesson planning activities carried out by the teacher using the CIRC model to improve grade IX students' reading skills.

\section{RESEARCH METHOD}

A method is an important way of researching because using the method will make it easier to achieve goals. The research method used in this research was the descriptive method with a qualitative approach. According to Craswell in Sugiyono (2014: 347), qualitative research is a process to explore and understand individual and group behavior describing social or human problems. For this reason, the author used it in the framework of analyzing and participating directly with those studied at SMP Negeri 1 Jampang Tengah, Sukabumi Regency. The subjects of this research were English teachers at SMP Negeri 1 Jampang Tengah Sukabumi Regency. In the Indonesian Dictionary (1989: 862), research subjects are people, places, or objects observed in research or targets. At least two things would influence the quality of the research: the research instrument and data collection. The data instrument is related to the validity and reliability of the instrument itself. The data collection techniques were related to the ways to obtain research data. In obtaining accurate and quality data, it was necessary to have data collection techniques following the research targets. Sugiyono (2014: 224) said that data collection techniques were the most strategic step in research. The primary purpose of the research was to get data. The research data collection techniques at SMP Negeri 1 Jampang Tengah Sukabumi Regency were carried out using observation, interviews, and documentation guidelines.

In this study, the observations were used to collect data on the learning management model of cooperative, integrated reading and composition to improve the English reading skills of students of Grade IX at SMP Negeri 1 Jampang Tengah, Sukabumi Regency. The observation activities were carried out by visiting the place under study directly during the learning process. The observations made were non-participatory, so 
that the researcher sat observing the teacher giving lessons during the research process without manipulating it.

The interviews used in this study were in-depth interviews because the study was directed to explore any information holistically and clearly from the informants. The interview activity was intended to obtain information about what the informants knew about the cooperative, integrated reading and composition model of learning management to improve the English reading skills of Grade IX students at SMP Negeri 1 Jampang Tengah, Sukabumi district. With two-way communication, the interviews made it easier for the researcher to understand the intended answers or information through the questions posed, depending on the interviewer's spontaneity.

Furthermore, the documentation study in this research was based on a document's notion as a written report of an event. It consisted of explanations and thoughts and was written on purpose to save or record information about events. Besides, it served as clues to find data sources.

\section{RESULTS AND DISCUSSION}

The results and discussion aimed to explain answers to the research questions in this study: what activities the teachers do in the lesson plan of Cooperative Integrated Reading and Composition to improve the Reading Skill of English for students in class IX SMP Negeri 1 Jampang Tengah Regency Sukabumi. The findings and discussion of the results as follows:

From the results of interviews with the English teacher at SMP Negeri 1 Jampang Tengah, it was revealed that:

"At the beginning of each new academic year, before the beginning of the learning process begins, we always hold a meeting with other teachers to prepare a teaching plan before learning begins, according to their respective subjects. The teaching plan is in the form of an Annual Program, Semester Program, Syllabus, and RPP (lesson plan)."

The relationship with the plan of CIRC (Cooperative Integrated Reading and Composition) learning model, the English teacher at SMP Negri 1 Jampang Tengah has implemented the Cooperative model with integrated reading types in learning Indonesian, English, Civics, and Religious subjects because there was reading aspect of these subjects.

"We already know the CIRC Cooperative type of learning model, and we have even applied it to subjects such as Indonesian, English, Civics, and Religious subjects because in these four subjects there are aspects of reading."

Furthermore, the results of interviews and documentation studies with English teachers at SMP Negeri 1 Jampang Tengah revealed that in terms of planning the CIRC (Cooperative Integrated Reading and Composition) model, the English teacher stated that:

"Our school is accustomed to conduct lesson planning activities at the beginning of the school year. These activities have become our duties as a teacher, including to plan cooperative learning planning activities for English 
subjects because it has four aspects. I use different types of the cooperative model. I do not follow all of the composition of integrated reading (Cooperative Integrated Reading and Composition) because it can only be applied to reading skills and models in English lessons other than CIRC, such as Role Play, NHT, TGT, SnowBall, Jigsaw, CTL, etc."

From the Annual Program made by the English teacher of SMPN 1 Jampang Tengah, it was revealed that the components of the Annual Program that were made contained an Identity (School Name, Subject, Class and Academic Year) and Field Form (Semester, Competency Standards, Basic Competencies, Main Materials, and Time Allocation).

Based on the interview, the teacher was concerned about formulating methods, models/techniques, and learning steps. They wanted to encourage active participation, develop the students' writing and reading habits, care about individual differences, help the students' difficulties during the learning process, provide solutions, and provide follow-up for further learning.

Before applying the Cooperative Integrated Reading and Composition learning model to improve students' English reading skills in class IX of SMP Negeri 1 Jampang Tengah, Sukabumi Regency, there require plans that must be done by the teacher. This planning is intended to direct learning so that it could run properly to achieve the goals. Without planning, learning would not be focused and will expand everywhere so that it is difficult for students to understand, and ultimately the learning objectives cannot be adequately achieved.

The result was aligned very well. It was associated with Madjid's theory (2006) which stated that in the context of learning plan could be interpreted as the process of compiling learning materials using learning media, approaches and methods, and also assessing an allocation of time which would be carried out at a certain time to achieve goals that have been determined. According to Hanafy (2017), learning was the stages of activities for teacher and students in carrying out learning programs, that is the activity plans that describe what is basic abilities and main theories to teach which in detail contain time allocations, indicators of achievement of learning outcomes, and learning steps for each subject matter.

In accordance with the results of interviews with English teachers at SMP Negeri 1 Jampang Tengah, It could be inferred that before carrying out the learning process, teachers must prepare plans in the form of an Annual Program, Semester Program, Syllabus and preparation of lessons plan (RPP), this is done to facilitate the learning process. Without planning, learning would run undirected and expand everywhere so that it was difficult for students to understand, and ultimately the learning objectives are not achieved properly.

The annual program was a plan to determine the learning schedules allocated for one year to achieve predetermined goals. Semester Program contains an outline of the things to be implemented and achieved in one semester. Semester Program is a translation of the Annual Program. A syllabus is a lesson plan for a particular subject/theme or group that includes competency Standards (CS), Basic Competencies 
(BC), learning materials, learning activities, indicators of competency achievement, assessment, time allocation, and learning resources.

The syllabus serves as a guide in developing further learning, such as making lesson plans, managing learning activities, and developing an assessment system. The syllabus is the primary source in preparing a lesson plan, both lesson plans for one competency standards (CS) and one basic competency (BC). The syllabus also functions as a guideline for planning the management of learning activities, for example, classical learning activities, small groups, or individual learning. Likewise, the syllabus is very useful for developing a grading system. In implementing competency-based learning, the assessment system always refers to competency standards (CS), Basic Competencies (BC), and indicators in the syllabus.

From the results of the research findings, it was revealed that in principle, the English teachers in the three schools had made a good syllabus so that they could answer questions (1) What to teach competency standards (CS), Basic Competencies (BC)), and Learning Materials; (2) How to implement learning activities, methods, media, (3) How to know the Competency Standards (CS), Basic Competencies (BC), had been achieved (indicators and assessments).

The final step in planning activities was to create a Learning Implementation Plan (RPP). Based on Government Regulation (PP) No. 19 of the Year 2005, Article 20 states that:

"The planning of the learning process includes a syllabus and a lesson plan that contains at least learning objectives, teaching materials, teaching methods, learning resources, and assessment of learning outcomes."

In accordance with Permendiknas (National Education Department) Number 41 of 2007 concerning process standards, it was explained that the lesson plans were described from the syllabus to direct student learning activities to achieve Basic Competencies. Every teacher in an educational unit was obliged to prepare a complete and systematic lesson plan. Learning took place in an interactive, inspirational, fun, challenging, motivating students to participate actively and provided sufficient space for initiative (effort), creativity, and independence according to their talents, interests, and students' physical and psychological development.

A lesson plan was prepared for each Basic Competency, which could be implemented in one or more meetings. The teacher designed the lesson plans for each meeting according to the schedule in the educational unit. The components of the lesson plan were as follows: (1) Identity of: School Name, Subject, Class, Semester, Competency Standards, Basic Competencies, Indicators, and Time Allocation; (2) Formulating Learning Objectives; (3) Determining Learning Materials; (4) Determining Learning Methods; (5) Defining Learning Activities; Preliminary Activities: Orientation, Appreciation, Motivation; Core Learning Activities: Exploration, Elaboration, Confirmation; Closing Activities; Choosing Learning Resources; Determine the Assessment. 
The research findings revealed that, in principle, the class IX English teachers at SMP Negeri 1 Jampang Tengah Sukabumi had made a lesson plan (RPP) well. In the lesson plan, there was an identification consisting of the school's name, subject, class, semester, type of text being taught, the skills to be achieved, and the time needed to work on the skills. The lesson plan should also include Standards Basic Competencies and Competencies, formulation of Learning Indicators and Goals to be achieved after students experience the learning process. In more detail, it could be described as follows:

a. Learning materials

In formulating learning materials, the school only wrote down the points or core of the learning material.

b. Techniques and methods/Learning Model

The school determined learning methods that were tailored to the material to be taught. What the researchers did was using the Cooperative Integrated Reading and Composition learning model that was related to students' reading skills.

c. Media and learning resources

The school used identical media and learning resources, including using relevant textbooks, reading scripts, relevant images, examples of functional texts.

d. Activity Phases

1) In the learning process, the duration of the learning process was two times 45 minutes. The teacher divided the time for preliminary activities (10') consisting of Orientation, Apperception, and Motivation;

2) Core learning activities (60') in deepening the material and closing activities (10') in feedback and reflection;

3) Because in one lesson plan, there could be more than one meeting, the learning steps could be several meetings;

4) In the steps, the activity started with an introduction, starting from giving greetings, asking about conditions, giving motivation, delivering learning objectives, and determining the time for approximately 10 minutes;

5) The next step was core activities; in the teacher's core activities carrying out the material's deepening, starting by providing interesting pictures following the material being taught to feel curious. Questions and answers related to the theme/topic or type of text being taught and provided reading material or text was studied to be more active during the learning process;

6) The next step is the closing activity.

e. Determine the Assessment

Determining assessment techniques that were tailored to the material, formulate Assessment Instruments, and determine assessment rubrics. 


\section{CONCLUSION}

The activities carried out by the teacher in planning the Cooperative Integrated Reading and Composition model in improving the reading skills of grade IX students at SMP Negeri 1 Jampang Tengah Sukabumi Regency consisted of: making an annual program by examining the educational calendar issued by the Sukabumi District Education Office, marking the holidays, calculating the number of effective weeks and distributing time allocations, making semester programs by determining competency standards, basic competencies, materials, and meeting time allocations, preparing syllabus by including competency standards (CS), basic competencies (BC), learning materials, activities learning, competency achievement indicators, assessment, time allocation, learning resources and character values, and preparation of lessons plan (RPP) that contain school identities, subjects, classes/semesters, academic years, competency standards, basic competencies, themes/types of text aspects/skills, allocation of time, learning objectives, expected student character, subject matter, learning methods, activity steps include: preliminary activities, core and closing activities, learning resources and assessment of learning outcomes. The learning planning activities of the Cooperative Integrated Reading and Composition learning model carried out by the English teacher concerned are in principle good and following the provisions and guidelines set by the government/education office of the Sukabumi district or by the school. Therefore, it was believed to achieve the specified competency standards and could improve reading skills in English. In addition to the concerned English teacher, the principal has a huge role in improving teacher professionalism through his guidance.

\section{REFERENCES}

Anita, Y. (2016). Penerapan Model Pembelajaran Kooperatif Tipe CIRC (Cooperative Integrated Reading And Composition) untuk Meningkatkan Kemampuan Siswa dalam Memecahkan Masalah Di SMP Negeri 1 Sipirok. Eksakta: Jurnal Penelitian Dan Pembelajaran MIPA, 8-18. https://doi.org/http://dx.doi.org/10.31604/eksakta.v1i1.\%25p.

Brown, H. D. (2001). Teaching by Principles: An Active Approach to Language Pedagogy (2nd ed.). San Francisco: Addison Wesley Longmen, Inc.

Halimah, A. (2014). Metode Cooperative Integrated Reading and Composition (CIRC) dalam Pembelajaran Membaca dan Menulis Di SD/MI. Auladuna, 1(1), 27-35. http://journal.uin-alauddin.ac.id/index.php/auladuna/article/view/539.

Hanafy, M. S. (2017). Konsep Belajar dan Pembelajaran. Lentera Pendidikan: Jurnal Ilmu Tarbiyah Dan Keguruan, 66-79. https://doi.org/https://doi.org/10.24252/lp.2014v17n1a5.

Harjono, B. (2011). Merangsang dan Melejitkan Minat Baca pada Anak Anda. Yogyakarta.

Huda, M. (2014). Model-Model Pengajaran dan Pembelajaran: Isu-Isu Metodis dan Pragmatis. Yogyakarta: Pustaka Pelajar.

Isjoni. (2010). Cooperative Learning Efektif Pembelajaran Kelompok. Bandung: Alfabeta. 
Mulyasa, E. (2015). Menjadi Guru Profesional Menciptakan Pembelajaran Kreatif dan Menyenangkan. Bandung: Remaja Rosdakarya.

Nurwanti. (2019). Student Interest in Learning Reading Comprehension of Expository Text toward Mind Mapping Technique. Cetta: Jurnal Ilmu Pendidikan, 2(3), 490500. http://jayapanguspress.penerbit.org/index.php/cetta/article/view/289.

Saddhono, \& Slamet. (2014). Pembelajaran Keterampilan Berbahasa Indonesia. Yogyakarta: Graha Ilmu.

Sagala, S. (2010). Konsep dan Makna Pembelajaran. Bandung: Alfabeta.

Sari, P. K., Rostini, D., Fajarianto, O., \& Safitri, Y. (2020). The Effect of Social Media on Reading Intensity of Fifth Grade Elementary School Students. Advances in Social Science, Education and Humanities Research, 429(Icasseth 2019), 215-218. https://doi.org/10.2991/assehr.k.200402.049.

Sirait, M. F., Hutauruk, B. S., \& Herman. (2020). The Effect of Using Speed Reading Technique to the Students ' Ability in Comprehending a Text. Cetta: Jurnal Ilmu Pendidikan, $3(3)$, $485-498$. http://jayapanguspress.penerbit.org/index.php/cetta/article/view/545/539.

Sugiyanto, R. (2010). Model-model pembelajaran Kooperatif. Surakarta: Yuma Pustaka.

Sugiyono. (2014). Metode Penelitian Pendidikan Pendekatan Kuantitatif, Kualitatif dan $R \& D$. Bandung: Alfabeta.

Yunus, M. (2016). Profesionalisme Guru dalam Peningkatan Mutu Pendidikan. Lentera Pendidikan: Jurnal Ilmu Tarbiyah Dan Keguruan, 19(1), 112-128. https://doi.org/https://doi.org/10.24252/lp.2016v19n1a10. 